\title{
PENGARUH FREKUENSI MEDIA DAN KETERPAPARAN INFORMASI TENTANG KB TERHADAP PERSEPSI JUMLAH ANAK IDEAL: ANALISIS DATA SDKI 2017
}

\section{Muhammad Ancha Sitorus ${ }^{1}$,Putra Apriadi Siregar ${ }^{2}$}

Email : putraapriadisiregar@uinsu.ac.id

${ }^{1}$ BKKBN Provinsi Sumatera Utara, Indonesia

2Universitas Islam Negeri Sumatera Utara, Indonesia

\section{ABSTRACT}

The National Population and Family Planning Board of North Sumatra Province continue to socialize the ideal number of children in a family of 2, but the TFR is still high at 2.9. Information about the Family Planning (KB) program expected to change people's thinking patterns about the number of children. Ideal. The research objective was the influence of media frequency and exposure to information about $k b$ on the perception of the ideal number of children. This study is a further analysis of the 2017 IDHS using a cross-sectional. The population in this study were all women of childbearing age 15-49 years. The sample in this study was 2300 WUS bivariate analysis using cross-tabulation and chi-square test. The results of this study indicate that the respondents who stated the ideal child were 1-2 people as many as $48 \%$ while $52 \%$ stated that the ideal child was $\geq$ three people. There is a relationship between the frequency of reading newspapers $(p=0.01)$, listening to the radio ( $p=0.028)$, watching TV $(P<0.001)$, using the internet $(P<0.001)$, reading exposure to family planning programs in newspapers (0.001), the radio (0.005), exposure to seeing family planning programs on TV (0.001) with the ideal number of children. The National Population and Family Planning Board of North Sumatra Province must be able to choose effective information media to increase public perceptions about the ideal number of children, such as urban communities better use radio and internet media and rural communities use newspaper information media.

\section{ABSTRAK}

Badan Kependudukan dan Keluarga Berencana Nasional Provinsi Sumatera Utara terus melakukan sosialisasi jumlah anak ideal didalam sebuah keluarga sebanyak 2 orang namun angka TFR masih tinggi sebesar 2,9.. Pemberian informasi tentang program Keluarga Berencana (KB) diharapkan dapat merubah pola berfikir masyarakat tentang jumlah anak ideal. Tujuan penelitian yaitu Pengaruh Frekuensi Media Dan Keterpaparan Informasi Tentang Kb Terhadap Persepsi Jumlah Anak Ideal. Penelitian ini merupakan analisis lanjut SDKI 2017 dengan menggunakan desain crossectional. Populasi dalam penelitian ini adalah seluruh wanita usia subur ( WUS) usia 10-49 tahun. Sampel dalam penelitian ini sebanyak 2300 WUS. Analisis bivariat menggunakan tabulasi silang dan uji chisquare. Hasil penelitian ini menunjukkan responden yang menyatakan anak ideal yaitu 1-2 orang sebanyak $48 \%$ sedangkan menyatakan anak ideal $\geq 3$ orang sebanyk 52\%. Terdapat hubungan antara frekuensi membaca koran $(p=0,01)$, mendengar radio $(\mathrm{p}=0,028)$, menonton $\mathrm{TV}(\mathrm{P}<0,001)$, penggunaan internet $(\mathrm{P}<0,001)$, keterpaparan membaca program KB di Koran $(0,001)$, keterpaparan mendengar program KB di radio $(0,005)$, keterpaparan melihat program KB di TV $(0,001)$ dengan jumlah anak ideal. Kepada Badan Kependudukan dan Keluarga Berencana Nasional Provinsi Sumatera Utara harus dapat memilih media informasi yang efektif untuk meningkatkan persepsi masyarakat tentang jumlah anak ideal seperti masyarakat di perkotaan lebih baik menggunakan media radio dan internet sedangkan masyarakat pedesaan menggunakan media informasi koran.

\section{Pendahuluan}

Program Keluarga Berencana di Indonesia dimulai secara intensif sejak tahun 1970 sejalan dengan berdirinya lembaga BKKBN (Badan Koordinasi Keluarga Berencana Nasional). Dibawah pemerintahan Orde Baru, program KB menjadi prioritas dan unggulan yang dilaksanakan dengan gegap gempita. Sebagai hasilnya, angka TFR yang sebelumnya mencapai 5,6 tahun 1970 menurun menjadi 2,8. Lalu laju pertumbuhan penduduk juga menurun dari 2,32 persen menjadi 1,3 persen. Akibatnya menurut perkiraan para ahli program KB masa orde baru bisa menghidari pertambahan sekitar 80 juta penduduk, karena seharusnya pada tahun 2000 Indonesia diproyeksikan akan memiliki 285 juta, tetapi bisa ditekan menjadi 205 juta jiwa (1). 
Tingginya jumlah penduduk yang tidak terkendali akan mengakibatkan beberapa permasalahan termasuk akan mengakibatkan permasalahan ketahanaan pangan dan tingginya jumlah penduduk miskin di Indonesia. Hasil sensus Badan Pusat Statistik (BPS) pada bulan Agustus 2010, jumlah penduduk Indonesia adalah 237.556.363 orang kemudian pada tahun 2015 sebanyak 266,91 juta jiwa dan semakin meningkat pada tahun 2019 menjadi 269,9 juta jiwa (2). Meningkatnya jumlah penduduk terjadi disebabkan angka kelahiran yang terus meningkat. Pada tahun 2017 angka kelahiran total ( Total Fertility Rate) sebesar 2,35 kemudian pada tahun 2,33 dan pada tahun 2018 sebesar 2,3, sementara itu BKKBN telah memberikan target untuk Total Fertility Rate (TFR) sebesar 2,0 untuk mengendalikan laju penduduk di Indonesia.

Dalam sepuluh tahun terakhir fertilitas di Indonesia tidak menunjukkan penurunan secara signifikan. Hasil Survei Demografi dan Kesehatan Indonesia (SDKI) 2007 dan 2012 menunjukkan angka fertilitas total (TFR) Indonesia stagnan pada 2,6 (3). Provinsi yang memiliki TFR sebesar 2,1 adalah Jawa Timur dan Bali. Kemudian dari data diatas juga terlihat provinsi yang TFR-nya sama dan dibawah rata-rata nasional yaitu TFR 2,4 adalah sebanyak 15 provinsi. Sehingga sisanya 19 provinsi berada pada posisi TFR diatas 2,4. Seluruh provinsi yang memiliki penduduk besar di pulau Jawa, memiliki TFR sama serta dibawah rata-rata nasional 2,4 .

Masyarakat di Indonesia masih menganggap jumlah anak ideal sebanyak 4-5 orang. Anak merupakan investasi bagi orangtuanya maka jumlah anak didalam keluarga akan meningkat (4). Hasil penelitian Novianty menunjukkan bahwa suami menginginkan jumlah anak lebih dari 2 (5). Provinsi Sumatra Utara menjadi salah satu provinsi diluar jawa yang memiliki penduduk besar (14.415.000) masih berada pada TFR 2,9 padahal pemerintah melalui BKKBN terus berupaya menurunkan TFR menjadi 2, 76 di Provinsi Sumatera Utara. BKKBN Provinsi Sumatera Utara memiliki program untuk menurunkan angka kelahiran total ( TFR) di Provinsi Sumatera Utara. Tinggi atau rendahnya nilai TFR yang terjadi dipengaruhi oleh peningkatan jumlah anak ideal dalam sebuah keluarga (6).

Pemerintah terus berupaya menekan laju angka kelahiran, namun ternyata banyak hambatan dalam pelaksanaan $\mathrm{KB}$, hal ini dapat dilihat masih banyaknya masyarakat yang masih menganggap jumlah anak ideal dalam sebuah keluarga sebanyak 4 sampai 5 orang anak. Motivasi untuk mempunyai jumlah anak yang sedikit dan nilai-nilai tentang anak merupakan aspek yang penting, sering terjadi didalam sebuah keluarga ditemukan jumlah anak yang diinginkan lebih besar daripada jumlah anak yang mampu dirawat dengan baik.

Besarnya angka kelahiran di masa mendatang secara tidak langsung dapat digambarkan dari jumlah kelahiran yang diinginkan dan jumlah anak ideal menurut remaja saat ini. Hal ini tentu bukan menjadi satu parameter mutlak karena respons atau persepsi yang disampaikan remaja dapat berbeda seiring bertambahnya usia dan pendidikan. Terdapat banyak hal dan faktor yang dapat memengaruhinya. Namun justru studi ini dapat menemukan dan merumuskan kebutuhan pasangan usia subur, khususnya akses terhadap media informasi tentang kesehatan reproduksi (7). Pasangan usia subur (PUS) yang memiliki 5+ anak terjadi disebabkan minimnya informasi yang didapatkan PUS tentang program KB (8). Akses terhadap sumber informasi akan berdampak terhadap pemahaman seseorang termasuk tentang kesehatan reproduksi (9) .

Wanita dengan pendidikan tinggi memiliki fertilitas yang lebih rendah dibandingkan fertilitas tinggi, pemberian informasi tentang program KB berdampak terhadap jumlah anak ideal (10). Hasil penelitian Harefa menunjukkan bahwa umur wanita, informasi tentang KB, tempat tinggal dan persepsi jumlah anak ideal berpengaruh terhadap penundaan kehamilan anak pertama pada wanita yang menikah dini di Pulau Jawa (11). Hasil penelitian Cenia dan Indraswari memperlihatkan bahwa persepsi usia menikah seseorang akan berdampak terhadap jumlah anak ideal yang diinginkan oleh seorang remaja (12);(13).

Keberlangsungan ber-KB tidak berjalan dengan lancar disebabkan kurangnya komunikasi informasi dan edukasi kepada masyarakat yang menggunakan media sosial dan elektronik (14). Media sebagai sarana untuk menyebarkan informasi termasuk informasi tentang kesehatan, 
Informasi yang diberikan kepada sebuah kelompok masyarakat akan memberikan dampak terhadap perilaku yang diambil kelompok tersebut (14). Hasil Penelitian Weni menemukan tiga faktor utama yang mempengaruhi pengetahuan KRR yakni: jenis kelamin; banyaknya jumlah sumber informasi; dan, pemanfaatan orang tua sebagai sumber informasi KRR (7).

Banyaknya jumlah anak yang dimiliki suatu keluarga, biasanya dilandasi oleh masih kuatnya ikatan sosial budaya terkait dengan nilai anak bagi keluarga yang kini masih menjadi pedoman dan tradisi kehidupan setiap keluarga. Seperti masih adanya pandangan anak sebagai karunia Tuhan yang tidak bisa ditolak, jaminan hari tua, anak sebagai pelanjut keturunan, penerus sejarah keluarga, pewaris nama, kepuasan batin, anak sebagai tanda keberhasilan perkawinan, yang semua ini merupakan warisan. BKKBN Provinsi Sumatera Utara sudah melakukan berbagai program untuk menurunkan angka kelahiran di Provinsi Sumatera Utara seperti program edukasi , sosilaisasi dan kampung KB. Jika angka kelahiran terus meningkat maka akan terjadi peningkatan jumlah penduduk yang memberikan dampak terhadap peningkatan jumlah beban tanggungan pada setiap kepala keluarga, baik dalam upaya pemenuhan pangan, sandang, pendidikan, kesehatan serta papan sebagai tempat tinggal manusia. Apabila hal tersebut tidak dapat dipenuhi maka akan menjadi permasalahan yang sangat serius bagi kelangsungan umat manusia diplanet bumi ini.

\section{Metode Penelitian}

Desain penelitian ini adalah potong lintang dan merupakan analisis lanjut data Survey Demografi Kesehatan Indonesia tahun 2017 (SDKI tahun 2017). Penelitian ini dilakukan di Provinsi Sumatera Utara yaitu 33 Kabupaten/Kota di Provinsi Sumatera Utara. Survey Rencana Pembangunan Jangka Menengah Nasional (SRPJMN) program Kependudukan, Keluarga Berencana dan Pembangunan Keluarga (KKBPK) dilaksanakan pada Bulan Februari hingga Bulan Mei tahun 2017. Survey berskala nasional ini dilaksanakan pada 34 provinsi di Indonesia dan untuk Provinsi Sumatera Utara, survey ini dilaksanakan di 33 kabupaten/kota dengan jumlah lokus 78 klaster yang dipilih dengan mempertimbangkan weighting dan kuintil kekayaan.

Populasi dalam penelitian ini adalah sampel individu Survey Demografi Kesehatan Indonesia tahun 2017 (SDKI tahun 2017) yaitu perempuan usia 15-49 tahun berasal dari Provinsi Sumatera Utara. Kriteria inklusi adalah wanita yang pernah menikah dan pada usia 15-49 tahun. Instrumen dan cara pengumpulan data pada studi ini memanfaatkan hasil pengumpulan data Survey Demografi Kesehatan Indonesia tahun 2017 (SDKI tahun 2017) yang dilakukan dengan wawancara menggunakan instrument kuesioner SDKI 17-WUS. Kuesioner rumah tangga digunakan untuk mencatat seluruh anggota rumah tangga dan tamu yang menginap semalam sebelum wawancara di rumah tangga terpilih, serta mencatat keadaan tempat tinggal rumah tangga terpilih.

Variabel independen dalam penelitian ini yaitu frekuensi baca koran (tidak pernah, kurang satu kali dalam seminggu dan satu kali dalam seminggu), frekuensi dengar radio (tidak pernah, kurang satu kali dalam seminggu dan satu kali dalam seminggu), frekuensi menonton TV (tidak pernah, kurang satu kali dalam seminggu dan satu kali dalam seminggu), penggunaan internet ( tidak pernah, ya selama 12 bulan yang lalu dan ya hampir setiap hari). Variabel dependen dalam penelitian ini yaitu jumlah anak ideal ( anak 1-2 orang dan anak $>2$ orang), membaca program KB di koran ( membaca program KB di koran dan tidak membaca program KB di koran), mendengar program $\mathrm{KB}$ di radio (mendengar program $\mathrm{KB}$ di radio dan tidak mendengar program KB di radio), melihat programm KB di TV (melihat programm KB di TV dan tidak melihat programm KB di TV). Analisis dilakukan dengan tabulasi silang kemudian disajikan dalam bentuk tabel distribusi frekuensi. Analisis bivariat menggunakan uji chisquare. dan analisis multivariat menggunakan uji regresi ordinal logistik. Interval kepercayaan dalam penelitian ini 95\%. 
Pengaruh Frekuensi Media dan Keterpaparan Informasi tentang KB terhadap Persepsi Jumlah Anak Ideal: Analisis Data SDKI 2017

\section{Hasil Penelitian}

Penelitian ini akan memberikan tampilan distribusi frekuensi variabel akses media dan keterpaparan program KB di media dan persepsi nilai jumlah anak ideal. Penelitian ini juga akan melakukan analisis uji chisquare untuk mengetahui pengaruh frekuensi media informasi dan keterpapran program KB di media terhadap persepsi jumlah anak ideal.

Tabel 1. Distribusi Tabulasi Silang Frekuensi Media Informasi dengan Persepsi Jumlah Anak Ideal

\begin{tabular}{|c|c|c|c|c|c|c|c|}
\hline \multirow[t]{2}{*}{$\begin{array}{l}\text { Frekuensi Membaca } \\
\text { Koran }\end{array}$} & \multicolumn{2}{|c|}{$\begin{array}{c}\text { Persepsi } \\
\text { Anak 1-2 Orang }\end{array}$} & \multicolumn{2}{|c|}{$\begin{array}{c}\text { Persepsi } \\
\text { Anak } \geq 3 \text { orang }\end{array}$} & \multicolumn{2}{|c|}{ Jumlah } & \multirow[t]{2}{*}{$\mathbf{P}$} \\
\hline & f & $\%$ & f & $\%$ & $\mathbf{F}$ & $\%$ & \\
\hline Satu Kali dalam Seminggu & 133 & 5,8 & 123 & 5,3 & 256 & 11,1 & 0,01 \\
\hline $\begin{array}{l}\text { Kurang Satu Kali dalam } \\
\text { Seminggu }\end{array}$ & 379 & 16,5 & 358 & 15,6 & 737 & 32 & \\
\hline Tidak Pernah Dengar & 591 & 25,7 & 716 & 31,1 & 1307 & 56,8 & \\
\hline Jumlah & 1103 & 48 & 1197 & 52 & 2300 & 100 & \\
\hline \multirow[t]{2}{*}{$\begin{array}{c}\text { Frekuensi Mendengar } \\
\text { Radio }\end{array}$} & \multicolumn{2}{|c|}{$\begin{array}{c}\text { Persepsi } \\
\text { Anak 1-2 Orang }\end{array}$} & \multicolumn{2}{|c|}{$\begin{array}{c}\text { Persepsi } \\
\text { Anak } \geq 3 \text { orang }\end{array}$} & \multicolumn{2}{|c|}{ Jumlah } & $\mathbf{P}$ \\
\hline & $\mathbf{f}$ & $\%$ & f & $\%$ & $\mathbf{F}$ & $\%$ & \\
\hline Satu Kali dalam Seminggu & 208 & 9 & 179 & 7,8 & 387 & 16,8 & \\
\hline $\begin{array}{l}\text { Kurang Satu Kali dalam } \\
\text { Seminggu }\end{array}$ & 282 & 12,3 & 300 & 13 & 582 & 25,3 & 0,028 \\
\hline Tidak Pernah Dengar & 613 & 26,7 & 718 & 31,2 & 1331 & 57,9 & \\
\hline Jumlah & 1103 & 48 & 1197 & 52 & 2300 & 100 & \\
\hline \multirow[t]{2}{*}{$\begin{array}{c}\text { Frekuensi Menonton } \\
\text { TV }\end{array}$} & \multicolumn{2}{|c|}{$\begin{array}{c}\text { Persepsi } \\
\text { Anak 1-2 Orang }\end{array}$} & \multicolumn{2}{|c|}{$\begin{array}{c}\text { Persepsi } \\
\text { Anak } \geq 3 \text { orang }\end{array}$} & \multicolumn{2}{|c|}{ Jumlah } & $\mathbf{P}$ \\
\hline & f & $\%$ & f & $\%$ & $\mathbf{F}$ & $\%$ & \\
\hline Satu Kali dalam Seminggu & 929 & 40,4 & 918 & 39,9 & 1847 & 80,3 & \\
\hline $\begin{array}{l}\text { Kurang Satu Kali dalam } \\
\text { Seminggu }\end{array}$ & 132 & 5,7 & 165 & 7,2 & 297 & 12,9 & $<0,001$ \\
\hline Tidak Pernah Dengar & 42 & 1,8 & 114 & 5 & 156 & 6,8 & \\
\hline Jumlah & 1103 & 48 & 1197 & 52 & 2300 & 100 & \\
\hline \multirow[t]{2}{*}{$\begin{array}{c}\text { Frekuensi Penggunaan } \\
\text { Internet }\end{array}$} & \multicolumn{2}{|c|}{$\begin{array}{c}\text { Persepsi } \\
\text { Anak 1-2 Orang }\end{array}$} & \multicolumn{2}{|c|}{$\begin{array}{c}\text { Persepsi } \\
\text { Anak } \geq 3 \text { orang }\end{array}$} & \multicolumn{2}{|c|}{ Jumlah } & $\mathbf{P}$ \\
\hline & f & $\%$ & f & $\%$ & $\mathbf{F}$ & $\%$ & \\
\hline Ya, Sebelum 12 bulan & 22 & 1 & 15 & 0,6 & 37 & 1,6 & \\
\hline Ya, 12 bulan yang lalu & 613 & 26,7 & 513 & 22,3 & 1126 & 49 & $<0,001$ \\
\hline Tidak Pernah Dengar & 468 & 20,3 & 669 & 29,1 & 1137 & 49,4 & \\
\hline Jumlah & 1103 & 48 & 1197 & 52 & 1103 & 48 & \\
\hline
\end{tabular}

Hasil penelitian ini menunjukkan bahwa frekuensi media informasi membaca koran satu kali dalam seminggu sebanyak 256 responden terdapat 133 responden menyatakan membaca koran satu kali dalam seminggu memiliki persepsi jumlah anak ideal 1-2 orang dan memiliki jumlah persepsi jumlah anak ideal $\geq 3$ orang sebanyak 123 responden. Dari 737 responden yang menyatakan frekuensi membaca koran kurang satu kali dalam seminggu menyatakan persepsi jumlah anak ideal 1-2 orang sebanyak 379 responden dan memiliki jumlah persepsi jumlah anak ideal $\geq 3$ orang sebanyak 358 responden. Dari 1307 responden yang menyatakan tidak pernah membaca koran menyatakan persepsi jumlah anak ideal 1-2 orang sebanyak 591 responden dan memiliki jumlah persepsi jumlah anak ideal $\geq 3$ orang sebanyak 716 responden.

Hasil penelitian ini menunjukkan bahwa frekuensi media informasi mendengar radio satu kali dalam seminggu sebanyak 387 responden terdapat 208 responden menyatakan mendengar radio satu kali dalam seminggu memiliki persepsi jumlah anak ideal 1-2 orang dan memiliki jumlah persepsi jumlah anak ideal $\geq 3$ orang sebanyak 179 responden. Dari 582 responden yang menyatakan frekuensi mendengar radio kurang satu kali dalam seminggu menyatakan persepsi jumlah anak ideal 1-2 orang sebanyak 282 responden dan memiliki jumlah persepsi jumlah 
anak ideal $\geq 3$ orang sebanyak 300 responden. Dari 1331 responden yang menyatakan tidak pernah mendengar radio menyatakan persepsi jumlah anak ideal 1-2 orang sebanyak 613 responden dan memiliki jumlah persepsi jumlah anak ideal $\geq 3$ orang sebanyak 718 responden.

Hasil penelitian ini menunjukkan bahwa frekuensi media informasi menonton TV satu kali dalam seminggu sebanyak 1847responden terdapat 929responden menyatakan menonton TV satu kali dalam seminggu memiliki persepsi jumlah anak ideal 1-2 orang dan memiliki jumlah persepsi jumlah anak ideal $\geq 3$ orang sebanyak 918 responden. Dari 297 responden yang menyatakan frekuensi menonton TV kurang satu kali dalam seminggu menyatakan persepsi jumlah anak ideal 1-2 orang sebanyak 132 responden dan memiliki jumlah persepsi jumlah anak ideal $\geq 3$ orang sebanyak 165 responden. Dari 156 responden yang menyatakan tidak pernah menonton TV menyatakan persepsi jumlah anak ideal 1-2 orang sebanyak 42 responden dan memiliki jumlah persepsi jumlah anak ideal $\geq 3$ orang sebanyak 114 responden.

Hasil penelitian ini menunjukkan bahwa frekuensi media informasi penggunaan internet satu kali dalam seminggu sebanyak 37 responden terdapat 22 responden menyatakan penggunaan internet sebelum 12 bulan memiliki persepsi jumlah anak ideal 1-2 orang dan memiliki jumlah persepsi jumlah anak ideal $\geq 3$ orang sebanyak 15 responden. Dari 1126 responden yang menyatakan frekuensi penggunaan internet yaitu kurang 12 bulan yang lalu menyatakan persepsi jumlah anak ideal 1-2 orang sebanyak 613 responden dan memiliki jumlah persepsi jumlah anak ideal $\geq 3$ orang sebanyak 513 responden. Dari 1137 responden yang menyatakan tidak pernah penggunaan internet menyatakan persepsi jumlah anak ideal 1-2 orang sebanyak 468 responden dan memiliki jumlah persepsi jumlah anak ideal $\geq 3$ orang sebanyak 669 responden. Hasil analisis uji chisquare menunjukkan bahwa terdapat hubungan frekuensi membaca koran $(0,01)$, frekuensi mendengar radio $(0,028)$, frekuensi menonton TV $(<0,001)$, frekuensi menggunakan internet $(<0,001)$ terhadap persepsi jumlah anak ideal di Provinsi Sumatera Utara

Tabel 2. Distribusi Tabulasi Silang Keterpaparan Media tentang Keluarga Berencana dengan Persepsi Jumlah Anak Ideal

\begin{tabular}{|c|c|c|c|c|c|c|c|}
\hline \multirow[t]{2}{*}{$\begin{array}{c}\text { Membaca Program KB di } \\
\text { Koran }\end{array}$} & \multicolumn{2}{|c|}{$\begin{array}{c}\text { Persepsi } \\
\text { Anak 1-2 Orang }\end{array}$} & \multicolumn{2}{|c|}{$\begin{array}{c}\text { Persepsi } \\
\text { Anak } \geq 3 \text { orang }\end{array}$} & \multicolumn{2}{|c|}{ Jumlah } & \multirow[t]{2}{*}{$\mathbf{P}$} \\
\hline & f & $\%$ & f & $\%$ & $\mathbf{F}$ & $\%$ & \\
\hline Membaca KB di Koran & 178 & 7,7 & 136 & 5,9 & 314 & 13,7 & \multirow[t]{2}{*}{0,001} \\
\hline $\begin{array}{llll}\text { Tidak } & \text { Membaca } & \text { KB di } \\
\text { Koran } & & & \\
\end{array}$ & 925 & 40,2 & 1061 & 46,1 & 1986 & 86,3 & \\
\hline Jumlah & 1103 & 48 & 1197 & 52 & 2300 & 100 & \\
\hline \multirow[t]{2}{*}{$\begin{array}{l}\text { Mendengar Program KB } \\
\text { di Radio }\end{array}$} & \multicolumn{2}{|c|}{$\begin{array}{c}\text { Persepsi } \\
\text { Anak 1-2 Orang }\end{array}$} & \multicolumn{2}{|c|}{$\begin{array}{c}\text { Persepsi } \\
\text { Anak } \geq 3 \text { orang }\end{array}$} & \multicolumn{2}{|c|}{ Jumlah } & \multirow[t]{2}{*}{$\mathbf{P}$} \\
\hline & f & $\%$ & f & $\%$ & $\mathbf{F}$ & $\%$ & \\
\hline \multirow{2}{*}{$\begin{array}{l}\text { Mendengar KB di Radio } \\
\text { Tidak Mendengar KB di } \\
\text { Radio }\end{array}$} & 131 & 5,7 & 100 & 4,3 & 231 & 10 & \multirow{3}{*}{0,005} \\
\hline & 972 & 42,3 & 1097 & 47,7 & 2069 & 90 & \\
\hline Jumlah & 1103 & 48 & 1197 & 52 & 2300 & 100 & \\
\hline \multirow[t]{2}{*}{$\begin{array}{l}\text { Melihat Program KB di } \\
\text { TV }\end{array}$} & \multicolumn{2}{|c|}{$\begin{array}{c}\text { Persepsi } \\
\text { Anak 1-2 Orang } \\
\end{array}$} & \multicolumn{2}{|c|}{$\begin{array}{c}\text { Persepsi } \\
\text { Anak } \geq 3 \text { orang }\end{array}$} & \multicolumn{2}{|c|}{ Jumlah } & \multirow[t]{2}{*}{$\mathbf{P}$} \\
\hline & f & $\%$ & f & $\%$ & $\mathbf{F}$ & $\%$ & \\
\hline Melihat Program KB di TV & 634 & 27,6 & 606 & 26,3 & 1240 & 53,9 & \\
\hline $\begin{array}{l}\text { Tidak Melihat Program KB } \\
\text { di TV }\end{array}$ & 469 & 20,4 & 591 & 25,7 & 1060 & 46,1 & 0,001 \\
\hline Jumlah & 1103 & 48 & 1197 & 52 & 2300 & 100 & \\
\hline
\end{tabular}

Hasil penelitian ini menunjukkan bahwa membaca program KB di koran sebanyak 314 responden terdapat 178 responden menyatakan membaca koran satu kali dalam seminggu 
memiliki persepsi jumlah anak ideal 1-2 orang dan memiliki jumlah persepsi jumlah anak ideal $\geq 3$ orang sebanyak 136 responden. Dari 1986 responden yang menyatakan tidak pernah membaca program KB di koran menyatakan persepsi jumlah anak ideal 1-2 orang sebanyak 925 responden dan memiliki jumlah persepsi jumlah anak ideal $\geq 3$ orang sebanyak 1061 responden.

Hasil penelitian ini menunjukkan bahwa mendengar program KB di radio sebanyak 231 responden terdapat 131 responden menyatakan mendengar program KB di radio memiliki persepsi jumlah anak ideal 1-2 orang dan memiliki jumlah persepsi jumlah anak ideal $\geq 3$ orang sebanyak 100 responden. Dari 2069 responden yang menyatakan tidak pernah mendengar program KB di radio menyatakan persepsi jumlah anak ideal 1-2 orang sebanyak 972 responden dan memiliki jumlah persepsi jumlah anak ideal $\geq 3$ orang sebanyak 1097 responden.

Hasil penelitian ini menunjukkan bahwa melihat program KB di TV sebanyak 1240 responden terdapat 634 responden menyatakan melihat program KB di TV memiliki persepsi jumlah anak ideal 1-2 orang dan memiliki jumlah persepsi jumlah anak ideal $\geq 3$ orang sebanyak 606 responden. Dari 1060 responden yang menyatakan tidak pernah melihat program KB di TV menyatakan persepsi jumlah anak ideal 1-2 orang sebanyak 469 responden dan memiliki jumlah persepsi jumlah anak ideal $\geq 3$ orang sebanyak 591 responden. Hasil analisis uji chisquare menunjukkan bahwa terdapat hubungan keterpaparan membaca program KB di Koran $(0,001)$, keterpaparan mendengar program KB di radio $(0,005)$, keterpaparan melihat program KB di TV $(0,001)$ terhadap persepsi jumlah anak ideal di Provinsi Sumatera Utara .

\section{Diskusi}

Jumlah anak yang diinginkan adalah banyaknya anak yang diinginkan dalam suatu keluarga dalam masa perkawinan. Setiap penduduk memiliki nilai budaya yang berbeda-beda, khususnya nilai budaya yang berkaitan dengan kehadiran sejumlah anak dari ikatan perkawinannya. Perbedaan keinginan memiliki sejumlah anak dari hasil ikatan tali perkawinan tersebut merupakan latar belakang setiap penduduk yang perlu diketahui guna menetapkan dan mempertimbangkan suatu prioritas dalam merencanakan jumlah anak yang diinginkan.

Hasil analisis uji chisquare menunjukkan bahwa terdapat hubungan frekuensi membaca koran $(0,01)$, frekuensi mendengar radio $(0,028)$, frekuensi menonton TV $(<0,001)$, frekuensi menggunakan internet $(<0,001)$ terhadap persepsi jumlah anak ideal di Provinsi Sumatera Utara. Banyak pasangan yang menginginkan hamil lagi dengan harapan mendapatkanjenis kelamin anak yang belum ada pada pasangan tersebut. Keinginan itu tentu saja tidak dapat dilepaskan dari nilai sosial budaya masyarakat yang masih menempatkan anak laki laki atau anak wanita yang lebih istimewa, yang antara lain tampak pada hukum ada dibeberapa daerah dalam hal warisan yang hanya diberikan kepada anak prianya atau anak wanitanya. Keinginan dalam memiliki sejumlah anak pada PUS nelayan adalah hasrat dalam diri PUS untuk memiliki sejumlah anak dengan tidak memandang jenis kelamin laki-laki maupun perempuan. Keinginan punya anak akan berdampak terhadap perilaku mereka dalam mencegah fertilitas seperting penggunaan kontrasepsi (7).

Kehadiran anak dalam keluarga sangatlah didambakan, karena anak adalah harapan keluarga. Anak mempunyai banyak arti dan fungsi bagi keluarga. Anak sangat didambakan baik dalam kelurga orang Desa maupun orang kota. Jumlah anak yang dimiliki PUS adalah banyaknya jumlah anak yang dilahirkan hidup oleh wanita PUS dari hasil perkawinan yang sah. Jumlah anak yang dimiliki setiap keluarga atau PUS berbedabeda jumlahnya dan jumlah yang dimiliki PUS dapat kita golongkan menjadi 2, yaitu keluarga kecil dan keluarga besar.

Nilai anak bagi orang tua dalam kehidupan sehari-hari dapat diketahui dari adanya kenyataan bahwa anak menjadi tempat orang tua mencurahkan kasih sayang. Anak sebagai tanda ikatan keberhasilan perkawinan, anak sering dijadikan pertimbangan oleh pasangan suami istri untuk membatalkan keinginan bercerai, kepada anak nilai-nilai dalam keluarga dapat disosialisasikan dan harta kekayaaan keluarga diwariskan. 
Banyaknya jumlah anak biasanya dilandasi oleh masih kuatnya ikatan sosial budaya terkait dengan nilai anak bagi keluarga yang kini masih menjadi pedoman dan tradisi kehidupannya. Seperti masih adanya pandangan anak sebagai karunia Tuhan yang tidak bisa ditolak, jaminan hari tua, ikatan perkawinan, anak sebagai pelanjut keturunan, penerus sejarah keluarga, pewaris nama, kepuasan batin, anak sebagai tanda keberhasilan perkawinan, yang semua ini merupakan warisan nilai-nilai. Hasil penelitian Siregar menunjukkan bahwa sosial budaya dan media menjadi salah satu faktor yang dapat mempengaruhi perilaku seseorang (15).

Keluarga yang belum mendapatkan anak dengan jenis kelamin yang sesuai dengan yang diinginkan maka besar keluarga ideal menurut persepsi keluarga belum tercapai. Bertambahnya jumlah anggota keluarga sebanyak dua orang maka akan meningkatkan jumlah anak yang diinginkan sebanyak satu anak. Salah satu alasan terbanyak keluarga responden menginginkan jumlah anak yang lebih banyak dari kondisi sekarang adalah menginginkan anak yang berjenis kelamin berbeda.

Hasil penelitian Alayubi dan Fella memperlihatkan bahwa nilai anak terhadap anak laki-laki dan anak perempuan berdampak terhadap jumlah anak pada PUS (16); (17). Hasil penelitian Khairunnisa memperlihatkan bahwa semakin banyak anggota keluarga (besar keluarga) berpengaruh terhadap jumlah anak ideal sebuah keluarga (18).

Banyak pasangan yang menginginkan hamil lagi dengan harapan mendapatkanjenis kelamin anak yang belum ada pada pasangan tersebut. Keinginan itu tentu saja tidak dapat dilepaskan dari nilai sosial budaya masyarakat yangmasih menempatkan anak pria atau anak wanita yang lebih istimewa, yang antara laintampak pada hukum ada dibeberapa daerah dalam hal warisan yang hanya diberikan kepada anak prianya atau anak wanitanya.

Akses media massa merupakan komunikasi satu arah. Model komunikasi satu arah kurang efektif karena bersifat instruktif, hanya berjalan satu arah dan disampaikan secara singkat (19). Media massa hanya sebagai media yang menginformasikan dan membuat orang sadar akan keberadaan KB. Untuk sampai kepada tindakan tetap diperlukan orang-orang yang secara personal mampu mempersuasi sasarannya (6). Penyuluhan yang dilakukan secara langsung atau bertatap muka sangat diperlukan dalam memengaruhi masyarakat karena terjalin komunikasi dua arah. Jadi, sesering apapun wanita mengakses media massa tentang informasi KB tidak berpengaruh terhadap penundaan kelahiran anak pertama karena belum diimbangi dengan kegiatan-kegiatan penyuluhan yang menerangkan langsung tentang informasi KB. Hal ini yang menyebabkan akses media massa terhadap informasi KB tidak signifikan dalam memengaruhi penundaan kelahiran anak pertama.

\section{Kesimpulan}

Secara sosiodemografi, WUS yang tinggal di daerah perkotaan memiliki tingkat pendidikan yang semakin tinggi cenderung memiliki jumlah anak ideal 1-2 orang. WUS yang memiliki akses terhadap media komunikasi diantaranya membaca koran, mendengar radio, menggunakan internet cenderung memiiki jumlah anak ideal 1-2 orang, namun akses berupa kunjungan PLKB tidak berpengaruh terhadap preferensi jumlah anak ideal. Tedapat hubungan antara sosiodemografi yaitu tempat tinggal(nilai $p<0,001$ ), tingkat pendidikan (nilai $p<0,001$ ) dengan jumlah anak ideal.Terdapat hubungan yang signifikan antara akses terhadap radio (nilai $\mathrm{p}<0,023$ ), akses terhadap internet (nilai $\mathrm{p}<0,023$ ) dengan jumlah anak ideal. Tidak ada hubungan antara kunjungan petugas lapangan $\mathrm{KB}(\mathrm{p}=0,376)$ dengan jumlah anak ideal wanita usia subur.

\section{Saran}

1. BKKBN Kabupaten/Kota harus lebih intens dalam melakukan sosialisasi informasi melalui media koran, radio dan internet dalam menyampaikan nilai anak dan jumlah anak ideal dalam sebuah keluarga, hal ini disebabkan media koran, radio dan internet terbukti berperan penting terhadap persepsi wanita usia subur tentang nilai anak dan jumlah anak ideal. 
2. Program Keluarga Berencana (KB) BKKBN Provinsi Sumatera Utara harus lebih intens untuk melakukan sosialisasi kepada masyarakat di perkotaan karena masyarakat di perkotaan memiliki keinginan memiliki anak yang lebih besar dibandingkan masyarakat di pedesaan terutama tentang nilai anak dan jumlah anak ideal dalam sebuah keluarga.

3. Keterlibatan Pelaksana Lapangan KB (PLKB) di setiap kecamatan dalam menyampaikan pesan Program Keluarga Berencana (KB) khususnya nilai anak dan jumlah anak ideal perlu ditingkatkan kepada wanita usia subur karena masih buruknya persepsi wanita usia subur tentang Pelaksana Lapangan KB (PLKB).

4. Materi yang disampaikan oleh Pelaksana Lapangan KB (PLKB) di setiap kecamatan diharapkan fokus kepada Program Keluarga Berencana tentang jumlah anak didalam keluarga hanya 2 orang saja baik anak laki-kaki dan anak perempuan.

\section{Daftar Pustaka}

1. BKKBN. Rencana Strategis Badan Kependudukan Keluarga Berencana Nasional Tahun 2015-2019. Jakarta; 2015.

2. BPS RI. Statistik Indonesia 2019. Jakarta; 2019.

3. Listyaningsih U, Sumini, Sonyaruri S. Unmet Need: Konsep Yang Masih Perlu Diperdebatkan Unmet Need : the Debatable Concept. Popuplasi. 2016;24:72-90.

4. Ruslan I. Nilai Anak" Dalam Perspektif Masyarakat Multi Etnik Dan Agama. J Pendidik Sosiol Dan Hum. 2017;8(2):1-10.

5. Novianty H. Analisis Dukungan Suami Terhadap Jumlah Anak Ideal. J Ners dan Kebidanan. 2016;3(1):13-27.

6. Alfana, M. A. F., Giyarsih, S. R., Aryekti, K., \& Rahmaningtias A. Fertilitas dan Migrasi: Kebijakan Kependudukan Untuk Migran Di Kabupaten Sleman. Natapraja. J Kaji Ilmu Adm Negara. 2015;3(1):1-10.

7. Weni L. Determinan Pemilihan Metode Kontrasepsi Jangka Panjang Pada Akseptor KB Aktif di Puskesmas Pedamaran. Contag Sci Period Public Heal Coast Heal. 2019;1(1):9-16.

8. Tirto DNK. Jumlah Anak Ideal Menurut Pasangan Usia Subur Di Kecamatan Mlati, Kabupaten Sleman, Daerah Istimewa Yogyakarta. J Ilmu Bumi. 2018;1(1):2018.

9. Sidabutar WH. Analisis Hubungan Antara Tingkat Keterpaparan Media dengan Tingkat Pemahaman Kesehatan Reproduksi Remaja di Provinsi Sumatera Utara. Inovasi. 2019;16(2):115-27.

10. Syakur RM. Analisis Faktor-Faktor yang Memengaruhi Tingkat Fertilitas di Kecamatan Watang Sawitto Kabupaten Pinrang. Universitas Islam Negeri Alauddin Makassar; 2018.

11. Harefa. Faktor-Faktor yang memengaruhi kecenderungan penundaan kehamilan anak pertama pada wanita yang menikah dini di Pulau Jawa tahun 2012. Sekolah Tinggi Ilmu Statistik; 2014.

12. Cenia A V. Persepsi Usia Menikah Ideal dengan Jumlah Anak yang Diinginkan Pada Remaja Kelas XI di SMA N 1 Depok Sleman Yogyakarta. Universitas ‘Aisyiyah; 2017.

13. Indraswari RR. Faktor-Faktor yang Memengaruhi Penundaan Kelahiran Anak Pertama di Wilayah Perdesaan Indonesia: Analisis Data SDKI 2012. J Kependud Indones. 2017;12(1):112.

14. Siregar PA. Promosi Kesehatan Lanjutan dalam Teori dan Aplikasi. Edisi Pert. Jakarta: PT. Kencana; 2020.

15. Siregar PA. Bahan Ajar Dasar Promosi Kesehatan. Medan: Universitas Islam Negeri Sumatera Utara.; 2020.

16. Alayubi MS. Faktor Penyebab Banyaknya Jumlah Anak pada PUS Keluarga Nelayan di Desa Subang Jaya Kecamatan Bandar Surabaya Kabupaten Lampung Tengah Tahun 2016. Universitas Lampung; 2018.

17. Fella N. Hubungan Pengetahuan dan Sikap KB dengan Jumlah Anak Terakhir pada PUS Akseptor di Kelurahan Pakintelan Kecamatan Gunungpati Kota Semarang Tahun 2015. Universitas Negeri Semarang; 2016.

18. Khairunnisa M. Hubungan Antara Sebaran Informasi Kampanye dengan Tingkat 
Pengaruh Frekuensi Media dan Keterpaparan Informasi tentang KB terhadap Persepsi Jumlah Anak Ideal: Analisis Data SDKI 2017

Keikutsertaan Pasangan Usia Subur ( PUS) dalam Program Pengendalian Kelahiran Anak (KB) Di Kelurahan Ujana, Kota Palu. J Komun KAREBA. 2015;4(4):468-81.

19. Sediyaningsi S. Analisis model komunikasi pembentukan konsep keluarga sejahtera di Indonesia (Studi terhadap sosialisasi program BKKBN Kota Depok dan Kota Bogor. J Organ dan Manaj. 2013;9(2):145-61. 